\title{
Dirty Words and Dirty Politics: Cognitive Dissonance in the First Amendment
}

Two kinds of speech that traditionally have not been accorded first amendment protection are libel and obscenity. ${ }^{1}$ Before 1964, libel law had developed a series of intricate rules designed to compensate damaged reputations and at the same time to allow specified classes of expression to pass untrammelled. However, in New York Times Co. $v$. Sullivan, ${ }^{2}$ the Supreme Court subjected the common law tests for libel to the scrutiny of the first amendment, ${ }^{3}$ adding the element of intent to what had previously been a two part test encompassing falsity and harm to reputation. The effect of the decision was to give more complete protection to those criticizing the government in print and, at the same time, to define narrowly the exceptions to that protection by which a plaintiff might recover damages for defamation.

In obscenity law, as developed since 1957, the Court employed a somewhat similar three part test ${ }^{4}$ to pare away from communications dealing candidly with sex those materials which were deemed obscene and without any redeeming social importance. Beginning with Roth v. United States, ${ }^{5}$ the Court struck a constitutional balance between the positive social value of discussions of sex and the ill effect that such materials might have on society. In the spring of 1966, however, the Court in three obscenity decisions ${ }^{\mathbf{b}}$ set about reordering the balance in order to make more precise the standards set out in Roth and subsequent cases. As in Times, the key to rebalancing was the element of defendant's intent. The use of the intent element in these cases, how-

1 See, e.g., Emerson, Toward a General Theory of the First Amendment, 72 YALE L.J. 877 (1963); Lockhart \& McClure, Literature, the Law of Obscenity, and the Constitution, 38 MINN. L. REv. 295 (1954).

2376 U.S. 254 (1964).

3 "[L]ibel can claim no talismanic immunity from constitutional limitations. It must be measured by standards that satisfy the First Amendment." Id. at 269.

I The test required that the materials in question be "patently offensive," that they appeal to "prurient interest," and that the seller have had some knowledge of the obscenity of his merchandise. See text accompanying notes $42-63$ infra.

5354 U.S. 476 (1957).

6 Mishkin v. New York, 383 U.S. 502 (1966); Ginzburg v. United States, 383 U.S. 463 (1966); Book Named "John Cleland's Memoirs of a Woman of Pleasure" v. Massachusetts, 383 U.S. 413 (1966). 
ever, was markedly different from the use of intent in Times and in previous obscenity cases; much confusion has followed. ${ }^{7}$

\section{The Multr-Threshold Test In Libel}

At common law, two discrete elements are necessary to a cause of action for libel: the writings must be false $e^{8}$ and defamatory of the plaintiff. The defendant has the burden of proving the truth of any defamatory remarks as legal justification for their publication. ${ }^{9}$ Since the harm against which libel law guards is injury to plaintiff's reputation $^{10}$-his character as others view him-mere falsity is not sufficient to make out a case. ${ }^{11}$ The plaintiff must also show that the statements taken as a whole ${ }^{12}$ defame him in the eyes of others, that they tend to hold him up to hatred, ridicule, or contempt. ${ }^{13}$

7 See, e.g., Magrath, The Obscenity Cases: Grapes of Roth, 1966 SuP. Gr. Rev. 7; The Supreme Court, 1965 Term, 80 HARv. L. REv. 91 (1966); Note, Obscenity and the Supreme Court: Nine Years of Confusion, 19 StAN. L. REv. 167 (1966); Note, More Ado About Dirty Books, 75 Yate L.J. 1364 (1966); 44 Texas L. REv. 1382 (1966).

8 This element originally applied to civil libel only. The English rule that truth is no defense in criminal libel was first adopted in this country in People v. Croswell, 3 Johns. Cas. 337 (N.Y. 1804). Statutes in nearly every state since have changed the rule. See also note 37 infra.

9 The defense of truth must extend to all defamatory imputations drawn from the publication. "Substantial," not literal, truth is required. See, e.g., Bell Publishing Co. v. Garrett Engineering Co., 154 S.W.2d 885 (Tex. Civ. App. 1941).

10 In describing the harm function of defamation, Professor Emerson, who distinguishes between words and actions in determining what the government may constitutionally regulate, says: "[T]he injury, at least in substantial part, does not flow from action resulting from the communication-action which can be intercepted by regulation addressed specifically to it-but directly from the communication itself. In this sense, therefore, true private defamation tends toward the category of 'action,' and hence is subject to reasonable regulation." Emerson, supra note 1, at 922.

11 Examples of the principle that even lies must be defamatory include Kimmerle v. New York Evening Journal, 262 N.Y. 99, 186 N.E. 217 (1933) (woman "courted by a murderer"); Cohen v. New York Times Co., 153 App. Div. 242, 138 N.Y.S. 206 (1912) (man is dead); Pogany v. Chambers, 206 Misc. 933, 134 N.Y.S.2d 691 (Sup. Ct. 1954) (brother of a Communist).

In addition, words used in anger are often not actionable. See, e.g., Hansen v. Dethridge, 67 N.Y.S.2d 168 (N.Y. City Ct. 1946) (accusation of libel); Tomakian v. Fritz, 75 R.I. 496, 67 A.2d 834 (1949) (“drunken driver'); Morrissette v. Beatte, 66 R.I. 73, 17 A.2d 464 (1941) (accusation of sodomy).

12 Statements that are clearly meant to be humorous and are so taken by readers would not be actionable, while a seemingly innocent statement may be devastating to the plaintiff, as in Braun v. Armour \& Co., 254 N.Y. 514, 173 N.E. 845 (1930), where plaintiff was said to have sold bacon in his store. Plaintiff was a kosher meat dealer.

13 See generally Gregory \& Kalven, Cases on Torts 947, 968-73 (1959); Prosser, Torts \$ 106 (3d ed. 1964); Developments in the Law of Defamation, 69 HARv. L. REv. 875, 892901 (1956). The statements need not be regarded as defamatory by a majority of the recipients, but only by "a considerable and respectable class in the community." Peck v. Tribune Co., 214 U.S. 185 (1909). 
The two elements of falsity and defamatory harm satisfied, plaintiff's case is complete. ${ }^{14}$ Libel law in a majority of jurisdictions does not require proof of an element of intent or negligence; ${ }^{15}$ absolute liability is the standard..$^{16}$ However, in raising a defense of privilege, the defendant may open up the question of his intent. Two categories of privilege may be pleaded by a defendant, defeasible and absolute, ${ }^{17}$ but only for the former is intent relevant.

Defeasible privilege is most important in the freedom it gives journalists and other critics in their discussions of public figures and public issues. ${ }^{18}$ The "fair comment" rule grants a qualified privilege to discussion not only of politicians and public officials, ${ }^{10}$ but also of writers, ${ }^{20}$

14 At common law, the jury is allowed to infer general damages from the defamatory nature of the remarks. However, in jurisdictions employing the distinction between libel per se (writings defamatory on their face) and libel per quod (writings defamatory in the light of extrinsic facts), special damages (pecuniary loss) must be proved for the latter. See, e.g., Rose v. Indianapolis Newspapers, Inc., 213 F.2d 227 (7th Cir. 1954); O'Connell v. Press Publishing Co., 214 N.Y. 352, 108 N.E. 556 (1915); Ellsworth v. Martindale-Hubbell Law Directory, Inc., 66 N.D. 578, 268 N.W. 400 (1936). See generally GREGORY \& KaLVEN, supra note 12, at 912-82; Developments, supra note 12, at 889-91.

15 A minority exception in cases concerning the defamation of public figures, including candidates for public office, was established in Coleman v. MacLennan, $78 \mathrm{Kan} .711,98$ Pac. 281 (1908), discussed in note 36 infra. The Times case turned this into a constitutionally required exception. See text accompanying notes 36-38 infra.

16 The early common law required an element of malice, but in Bromage v. Prosser, 4 B. \& C. 247, 107 Eng. Rep. 1051 (1825), the fiction of "malice in law" was created, with no proof of ill will or lack of honest belief required.

17 Absolute privilege exists in four areas:

1) For legislators. U.S. CoNST. art. I, § 6: "[F]or any Speech or Debate in either House, they shall not be questioned in any other Place." Many state constitutions have similar provisions for state legislators.

2) For persons involved in judicial proceedings. See, e.g., Hayslip v. Wellford, 195 Tenn. 621, 263 S.W.2d 136 (1933), cert. denied, 346 U.S. 911 (1954) (grand juror); Dunham v. Powers, 42 Vt. 1 (1868) (petit juror); Massey v. Jones, 182 Va. 200, 28 S.E.2d 623 (1944) (witness); Scott v. Stansfield, L.R. 3 Ex. 220 (1868) (judge).

3) For persons in executive government offices. See, e.g., Barr v. Matteo, 360 U.S. 564 (1959) (lower federal officers and employees making authorized communications in the performance of their duties); Spalding v. Vilas, 161 U.S. 483 (1896) (Postmaster General).

4) When plaintiff explicitly consents to the libel. See, e.g., Shinglemeyer v. Wright, 124 Mich. 230, 82 N.W. 887 (1900).

18 Newspapers may report records of public proceedings, even though defamatory, provided their report is accurate. See, e.g., Cresson v. Louisville Courier-Journal, 299 Fed. 487 (6th Cir. 1924) (report of majority of congressional committee).

In the private arena, an individual has the right to verbal self-defense. Israel v. Portland News Publishing Co., 152 Ore. 225, 53 P.2d 529 (1936). Statements furthering the interests of a third party where some duty to make the communication exists will be privileged. Toogood v. Spyring, 1 C.M. \& R. 181, 149 Eng. Rep. 1044 (Ex. 1834). Discussion by a group of mutual interests is privileged. See, e.g., Slocinski v. Radwan, 83 N.H. 501, 144 Atl. 787 (1929) (congregation members discussing morals of their minister).

10 See, e.g., Bailey v. Charleston Mail Ass'n, 126 W. Va. 292, 27 S.E.2d 837 (1943).

20 See, e.g., Potts v. Dies, 132 F.2d 734 (D.C. Cir. 1942) (magazine article writer). 
sports figures, ${ }^{21}$ entertainers, ${ }^{22}$ and others whose activities or beliefs make them public figures. ${ }^{23}$ Under this rule, error as to opinion is privileged, but, in a majority of jurisdictions, error as to fact is not. ${ }^{24}$ The obvious policy of the rule is to encourage open discussion and criticism of issues and people in the public eye, albeit with factual accuracy rigorously required. Further justification lies in the notion that most people who might be defamed under the rule have voluntarily exposed their works or themselves in certain capacities to the public. Their reputations are, to some extent, public property.

The most significant limitation on this and other defeasible privileges is the intent with which the defamer publishes his remarks. A showing of malice, that the defendant published his remarks out of ill will for the plaintiff, will generally defeat the privilege. Similarly, defendant's disbelief in his own opinions, excessive vehemence in his defamation, or unnecessary communication of the remarks to persons having no legitimate interest in them, all work to defeat the privilege. The plaintiff must show that defendant abused the policy behind the privilege, that is, that the defendant was not attempting to obtain truth for his readers by open discussion of public issues and public figures. ${ }^{25}$

In the Times case, the Court decided that such limited privilege, combined with the basic elements of falsity and defamatory harm, did not sufficiently protect the freedom of the press to report on public issues and to comment on the activities of public officials. ${ }^{26}$ Although aware that the defendant's advertisement ${ }^{27}$ contained several factual

21 See, e.g., Cohen v. Cowles Publishing Co., 45 Wash. 2d 262, 273 P.2d 893 (1954) (jockey's handling of horse).

22 See, e.g., Cherry v. Des Moines Leader, 114 Iowa 298, 86 N.W. 323 (1901) (singerdancer).

23 See, e.g., Brewer v. Hearst Publishing Co., 185 F.2d 846 (7th Cir. 1950) (alternative holding) (proponent of vivisection).

24 The minority xule of nine states established in Coleman v. MacLennan, 78 Kan. 711, 98 Pac. 281 (1908), permits good faith error as to fact. See note 15 supra.

25 In a more general statement of the rule: "One who upon a conditionally privileged occasion publishes false and defamatory matter of another abuses the occasion if he does not act for the purpose of protecting the particular interest for the protection of which the privilege is given." Restatement, TorTs $\S 603$ (1938).

26 The Court alluded to the unequal treatment afforded government officials, who have an absolute privilege to libel, as compared to that afforded the press: "It would give public servants an unjustified preference over the public they serve, if critics of official conduct did not have a fair equivalent of the immunity granted to the officials themselves." 376 U.S. at 282-83.

27 Plaintiff in the Times case was the police commissioner of Mongomery, Alabama, who was allegedly libelled in a full-page advertisement concerning racial disturbances in that city. 
errors, the Court considered the case "against the background of a profound national commitment to the principle that debate on public issues should be uninhibited, robust, and wide-open, and that it may well include vehement, caustic, and sometimes unpleasantly sharp attacks on government and public officials." 28 On this basis, the Court proceeded to attack the sufficiency of truth as a test for libel. The Court noted that robust debate cannot avoid misstatements of fact and requires that untruths be tolerated to give "breathing space" to free speech; ${ }^{29}$ to force all critics of government to be completely accurate as to facts would in effect impose "self-censorship" on publishers. ${ }^{30}$ The Court concluded that the "accuracy as to facts" rule closely resembled in effect a law for seditious libel, ${ }^{31}$ in that it could well quash all controversial comment on government and its officials. ${ }^{32}$

The Court then turned to the second element-harm to reputation. Assuming that the statements in the Times advertisement sufficiently identified the plaintiff and defamed him, ${ }^{33}$ the Court found irrelevant the question of harm to his reputation as a public official. ${ }^{34}$ It reasoned that to allow such harm as grounds for recovery would, again, take on the character of a prosecution for seditious libel. That harm to the official's private reputation might ensue was recognized by the Court but was given little weight on the policy scales of the first amendment. In a sense, the Court was creating a "deep-pocket" theory of defamatory harm to reputation; the government can afford defamatory criticism because of its very publicness, and because of its opportunity and resources to right the harm through ability to reply. ${ }^{35}$

While the Court's decision in Times did not end the significance of

28376 U.S. at 270 . Speaking of this policy two years later, the Court said: "The thrust of New York Times is that when interests in public discussion are particularly strong, as they were in that case, the Constitution limits the protections afforded by the law of defamation." Rosenblatt v. Baer, 383 U.S. 75, 86 (1966).

29 "[E]rroneous statement is inevitable in free debate, and . . . it must be protected if the freedoms of expression are to have the 'breathing space' that they 'need . . . to survive,' NAACP v. Button, 371 U.S. 415,433 . . ." 376 U.S. at 271-72.

30 Id. at 279. The Court cited Smith v. California, 361 U.S. 147 (1959).

31376 U.S. at 279. Earlier the Court noted that: "Although the Sedition Act was never tested in this Court, the attack upon its validity has carried the day in the court of history." Id. at 276. See also Kalven, The New York Times Case: A Note on "The Central Meaning of the First Amendment," 1964 Sur. Cr. REv. 191, 209.

32 The threat of enormous damage awards of itself would deter any substantial criticism. The Court noted that the Times advertisement was the subject of five civil suits with damage claims totalling $\$ 3,000,000$. 376 U.S. at 277-78 n.18.

33 The Court subsequently found the identification element wanting. $I d$. at 288-92.

34 "Injury to official reputation affords no more warrant for repressing speech that would otherwise be free than does factual error." Id. at 272 .

35 Id. at 304-05 (concurring opinion). 
truth and defamatory harm in the test for libel of public officials, it forcefully indicated their inadequacy as insulators of a constitutionally desirable degree of uninhibited discussion. Thus, while truth and defamatory harm were retained as thresholds which must be met to put the statement inside the common law boundary of libel, the Court in Times added a third- "actual malice"-as another independent hurdle in a multi-threshold test designed to increase protection of first amendment freedoms.

As defined in Times, "actual malice" 36 exists when a statement is shown to have been made "with knowledge that it was false or with reckless disregard of whether it was false or not."37 Mr. Justice Brennan, the author of the Times opinion, later noted: "The underpinning of that qualification (actual malice) is the 'redeeming social value' test." 38 Thus, opinions based on facts known to be false or recklessly asserted are without redeeming social value and need not be constitutionally protected. While negligent misstatements of fact are equally harmful, the Court gave them leeway pursuant to its announced policy of granting "breathing space," or overprotecting all speech to protect that which is of value.

In addition, the new actual malice threshold greatly altered the impact of the truth element in this area of libel law. Now that the plaintiff is required to prove that the defendant knowingly or reck-

36 The phrase was borrowed from the Coleman rule, cited by the Court as a precedent for the Times decision. Id. at 280-82. The Goleman rule, however, permitted an action based on misstatements of fact when plaintiff proved the publisher's lack of "good faith" as to the truth of the facts reported. Coleman v. MacLennan, 78 Kan. 711, 723, 98 Pac. 281, 285 (1908); see note 15 supra.

37 376 U.S. at 280 . The new definition also has the effect of erasing the old "ill will" definition of malice, as the Court emphasized in Garrison v. Louisiana, 379 U.S. 64 (1964), a criminal libel case in which a district attorney was charged with libeling eight parish Criminal District Court judges. The Court did not rule unconstitutional all criminal libel statutes, but said that the Times version of actual malice was required in all such cases.

Professor Emerson, quoted favorably in Garrison, 379 U.S. at 69, finds no justification for any criminal libel statute in light of his distinction between actions and words: "[T]he harm to be prevented is the action, in the nature of disorder or similar conduct, which it is feared may flow from the utterance. In this, it [criminal libel] differs from civil libel where ... there was no action distinct from the communication itself which could . be intercepted by regulation ... [Thus] criminal libel prosecutions cannot be classified as 'action.' The prior balancing in favor of protecting expression . . . here compels acceptance of the legal doctrine that criminal libel laws are invalid." Emerson, supra note 1 , at 924 .

38 Brennan, The Supreme Court and the Meiklejohn Interpretation of the First Amendment, 79 HARv. L. REv. 1, 18-19 (1965). "[The malice requirement] eliminates only expression which is of limited social value. Deliberate publication of misinformation, it is assumed, serves no useful purpose. In fact, it is a disservice to the public." Berney, Libel and the First Amendment-A New Constitutional Privilege, 51 VA. L. REv. 1, 53 (1965). 
lessly published untruthful defamatory remarks, the Court has in effect shifted the burden of proof with regard to truth; it will be very difficult for a plaintiff to prove malice without first proving the falsity of the statement in question. Hence, of the "three 'galloping presumptions' of damage, falsity, and malice," 39 at least two, falsity and malice, have been harnessed.

It should be noted that Times has affected only a portion of libel law and does not even cover the full scope of situations to which the fair comment privilege applies. Subsequent cases, however, have expanded the definition of "public official" to such an extent that the multithreshold test of Times may ultimately replace fair comment altogether..$^{40}$ Such a result would substantially reduce the number of libel suits and would greatly enlarge the scope of social criticism through the press. But whatever the breadth of its future application, the central thrust of the Court's approach in Times remains. The new test adds a third and independent threshold to those already in existence, establishing a multi-threshold test further to protect the public interest in free and open discussion of public officials.

\section{Pornography Per Se, Prurient Appeal, and Pandering}

Obscenity law as it has evolved from the Court's 1957 decision in Roth has focused on three elements-patent offensiveness, harmful effect on audience, and the distributor's intent-which may be viewed as establishing a multi-threshold test analogous to that developed for libel in Times. In obscenity, as in libel, the three part test has been applied to determine what speech is within the protection of the first amendment and what may be regulated.41 Parallels drawn between the elements of these tests may be used further to evaluate the multithreshold approach to speech problems.

The first threshold in obscenity is that the publication must be intrinsically indecent, regardless of its use or its audience. "[S]ex and obscenity are not synonymous." 42 The standard was clarified in Manual

39 Kalven, supra note 31, at 196.

40 See, e.g., Rosenblatt v. Baer, 383 U.S. 75 (1966) (appointees of elected town park commissioners); Pauling v. Globe-Democrat Publishing Co., 362 F.2d 188 (8th Cir. 1966) (famous scientist); Pauling v. News Syndicate Co., 335 F.2d 659 (2d Cir. 1964) (dictum) (famous scientist); Walker v. Courier-Journal and Louisville Times Co., 246 F. Supp. 231 (W.D. Ky. 1965) (famous general); cf. Linn v. United Plant Guard Workers of America, Local 114, 383 U.S. 53 (1966) (company executive in union dispute); Time, Inc. v. Hill, 87 Sup. Ct. 534 (1967).

41 "We hold that obscenity is not within the area of constitutionally protected speech or press." Roth v. United States, 354 U.S. 476,485 (1957).

42 Id. at 487 . 
Enterprises, Inc. $v$. Day, ${ }^{43}$ where it was held that materials had to be "patently offensive" in order to be found obscene. Without this initial threshold test, the Court argued, many of our most respected works of art and literature would be taken from the reading public. "[S]uch a construction (of the statute) . . . would doubtless encounter constitutional barriers." 44

The "effect" element constitutes the second threshold. ${ }^{45}$ Material is obscene when, "to the average person, applying contemporary community standards, the dominant theme of the material taken as a whole appeals to prurient interest." 46 The Court is concerned here with the effect that obscene materials have on their audience-the harm which the legislature is presumably attempting to prevent through its imposition of criminal sanctions. ${ }^{47}$ As in defamation, the publication must be taken as a whole, a reaction against the old rule of Regina $v$. Hicklin. ${ }^{48}$ A second reaction to the Hicklin test is the requirement that prurient appeal be measured by the standard of the "normal person." 49 This standard also reflects the Court's decision in Butler v. Michigan, ${ }^{50}$

43370 U.S. 478, 482 (1962). See also Modec Penal Code \& 251.4(1) (Proposed Official Draft, 1962) ("Material is obscene if, . . . it goes substantially beyond customary limits of candor in describing . . . such matters (sex)." Accord, Jacobellis v. Ohio, 378 U.S. 184, 191-92 (1964).

The element was introduced to avoid making a determination of prurient appeal to a specific audience. See text accompanying notes 52-53 infra. The Court held that the materials had to be "patently offensive" to the national community.

44370 U.S. at 487.

$45 \mathrm{Id}$. at 484 .

46 Roth v. United States, 354 U.S. 476,489 (1957).

47 Professor Emerson, in discussing the social harm caused by obscenity, uses his words-actions distinction to reject the justification for regulation that obscenity leads to antisocial conduct or unpopular morals. However, he does find some harm where children receive the materials, and "where a shock effect is produced by forcing an 'obscene' communication upon a person contrary to his wishes, the issue is somewhat similar to that involved in private defamation. The harm is direct, immediate, and not controllable by regulating subsequent action." Emerson, supra note 1, at 938 .

Professors Lockhart and McClure define the harm element as the nourishing of "erotic fantasies" or "psychic autoeroticism." Lockhart \& McClure, Censorship of Obscenity: The Developing Constitutional Standards, 45 MinN. L. Rev. 5, 65 (1960).

Professor Kalven lists four possible evils that might flow from obscenity. He finds three set aside by the Court and the fourth, "the arousing of revulsion and disgust in a noncaptive audience," as "too trivial a predicate for constitutional regulation." Kalven, The Metaphysics of the Law of Obscenity, 1960 SUP. CT. REv. 1, 41-42. Whether he would agree with Emerson about harm to children and captive adult audiences is not stated.

48 [1868] 3 Q.B. 360. The Hicklin test allowed a court to pick out the most offensive passages and judge the entire publication on their appeal to those persons most susceptible to then.

49 Roth v. United States, 354 U.S. 476,489 (1957).

50352 U.S. 380 (1957). "The State insists that, by thus quarantining the general reading public against books not too rugged for grown men and women in order to shield 
in which a state law banning for all readers any books tending to influence minors adversely was held unconstitutional. The first amendment does not allow abridgement of the freedom to listen for everyone when there is reason only to regulate for a few.

Just as libelous statements must be found defamatory in the eyes of those to whom they are addressed, publications in obscenity litigation must be shown to be "obscene" in the eyes of their audience. In this respect the Court continued to be tied to the idea of a national audience as a result of Butler and Roth until the 1966 cases, ${ }^{51}$ where, in the Mishkin decision, the Court adopted the Lockhart and McClure concept of "variable obscenity:"62

We adjust the prurient-appeal requirement to social realities by permitting the appeal of this type of material to be assessed in terms of the sexual interests of its intended and probable recipient group. ${ }^{53}$

The adjustment of the audience rule not only introduced social realities; it also helped the Court to find something obscene for the first time since the Roth case was decided. The Court realized in obscenity what the law of libel has recognized for a long time-that the materials have their ill effect not in the abstract, but in the eyes of their recipients.

The flip side of the prurient interest coin, the "privilege" in obscenity law, ${ }^{54}$ is the requirement that the publication in question be "utterly without redeeming social value." 55 The "social value" test has greater

juvenile innocence, it is exercising its power to promote the general welfare. Surely, this is to burn the house to roast the pig." 352 U.S. at 383.

51 See, e.g., Jacobellis v. Ohio, 378 U.S. 184, 192-95 (1964). But lower federal courts had already made some efforts to employ a variable obscenity test, with some confusion. See, e.g., United States v. Klaw, 350 F.2d 155 (2d Cir. 1965); United States v. One Carton Positive Motion Picture Film Entitled "491," 247 F. Supp. 450 (S.D.N.Y. 1965).

52 Lockhart \& McClure, supra note 47 at 77: "Under variable obscenity, material is judged by its appeal to and effect upon the audience to which the material is primarily directed. In this view, material is never inherently obscene; instead, its obscenity varies with the circumstances of its dissemination." The Court did not rule out the possibility of finding materials obscene in a neutral context, but its reversal in Memoirs and the results of Ginzburg and Mishkin indicated the improbability of such a judgment in the future.

53 Mishkin v. New York, 383 U.S. 502, 509 (1966).

54 Kalven, supra note 47 , at 15 : "[T] he Court is giving a constitutional privilege to all communication that has some social value."

55 Book named "John Cleland's Memoirs of a Woman of Pleasure" v. Massachusetts, 383 U.S. 413, 419 (1966). See also Jacobellis v. Ohio, 378 U.S. 184, 191 (1964). For purposes of this analysis, social value is regarded as a part of the ill effect threshold, although it must be remembered that the rule requires the social value criterion to be determined independently of prurient appeal. 
force than a privilege in defamation, however, in that it is an element that must be proved in addition to prurient appeal in order to meet the ill effect threshold. Recognizing that much literature can be found to appeal to someone's prurient interest, ${ }^{56}$ the Court has built in this safeguard to further isolate those materials it deems socially harmful. Any publication that in some way contributes to art, literature, or thought is protected, regardless of its appeal to prurient interest. "Ceaseless vigilance" must be employed to protect open discussion of "sex, a great and mysterious motive force in human life, . . . indisputably ... a subject of absorbing interest to mankind through the ages; it is one of the vital problems of human interest and public concern." Hence, a state may not ban materials for advocating sexually provocative ideas. ${ }^{58}$ Nor may a novel with even minimal literary value be banned. ${ }^{59}$ The Court has apparently extended the same kind of protection to literature and the arts that it gave to political discussion in Times;" ${ }^{\circ 0}$ Professor Kalven's plea that "beauty has constitutional status too" appears to have been heard. ${ }^{61}$

Before 1966 the question of intent had never played a very important role in obscenity prosecutions, simply because the Court was usually concerned with whether the materials in question were to be banned, and not with the fate of the publishers and distributors. The so-called "social value" privilege had been absolute, 62 the burden falling on

56 "[O]ne would not have to travel far even among the acknowledged masterpieces in any of these fields [literature, art, and science] to find works whose 'dominant theme' might, not beyond reason, be claimed to appeal to the 'prurient interest' of the reader or observer." Manual Enterprises, Inc. v. Day, 370 U.S. 476, 485 (1957).

57 Roth v. United States, 354 U.S. 476, 487-88 (1957).

58 Kingsley Int'l Pictures Corp. v. Regents of the University of the State of New York, 360 U.S. 684 (1959) (movie based on Lady Chatterley's Lover portraying adultery as a good thing).

59 Book named "John Cleland's Memoirs of a Woman of Pleasure" v. Massachusetts, 383 U.S. 463 (1966).

60 The groundwork for this position was laid in Joseph Burstyn, Inc. v. Wilson, 343 U.S. 495, 501 (1952), quoting favorably from Winters v. New York, 333 U.S. 507, 510 (1948): "The line between the informing and the entertaining is too elusive for the protection of that basic right [a free press]. Everyone is familiar with instances of propaganda through fiction. What is one man's amusement, teaches another's doctrine."

Similarly in Times the Court declared: "Like . . o obscenity, . . . libel can claim no talismanic immunity from constitutional limitations. It must be measured by standards that satisfy the First Amendment." 376 U.S. at 269.

For a narrower view, restricting the scope of the first amendment to "religious and political freedom," see Meiklejohn, What Does the First Amendment Mean?, 20 U. CHI. L. REv. 461, 464 (1953).

61 Kalven, supra note 47 , at 16.

62 See, e.g., Jacobellis v. Ohio, 378 U.S. 184 (1964). The Court never reached the question of the intent of the movie distributor convicted below, because it found the movie itself not obscene. 
the prosecution to show that the materials had no social value. The Court's only word on the subject of intent came in Smith $v$. California, ${ }^{63}$ where a bookseller was convicted of selling obscene literature under a state absolute liability statute. The Court held the statute unconstitutional on the ground that it would require all sellers to be closely familiar with the contents of all their books and to become their own censors. To avoid risk of prosecution, sellers would probably take many books off their shelves that might conceivably run afoul of the obscenity statute, thus depriving the public of much worthwhile reading. The Court ruled that any such statute would have to include some element of scienter, although it did not specify how this provision should be drawn. The requirement of a mens rea element here is not as a limit to privilege, as in defamation, but rather as a further protection for distributors of materials dealing with sex. In this sense the Court's use of the intent element was similar to its use in Times: rather than making the defendant prove good intent to justify his actions, the defendant's mens rea becomes a third, independent threshold for the prosecution to meet.

\section{III. "Commercial Exploitation": A NEW Element}

The 1966 obscenity cases subverted the thrust of the multi-threshold test. The Court began in Memoirs where, after finding the controver- sial novel Fanny Hill not obscene in a neutral context, it delivered the following dictum:

Evidence that the book was commercially exploited for the sake of prurient appeal, to the exclusion of all other values, might justify the conclusion that the book was utterly without redeeming social importance. ${ }^{64}$

In its holding, the Court relied on the point that evidence at trial had shown the novel to have "some" redeeming social value. Its dictum suggested that the novel could be the subject of further prosecutions should evidence arise of distributors marketing the book solely on its "prurient appeal." In clarifying this point, the Court stated:

It is not that in such a setting the social value test is relaxed so as to dispense with the requirement that a book be utterly devoid of social value, but rather that, as we elaborate in Ginzburg v. United States, post, . . . where the purveyor's sole emphasis is on the sexually provocative aspects of his publications, a court could accept his evaluation at face value. ${ }^{85}$ 
The suggestion from Memoirs was iterated in the Court's analysis in Mishkin. The Court first made the adjustment of the audience requirement mentioned above and determined that the materials themselves appealed to the prurient interest of the "intended and probable recipient group," independent of defendant's pandering. ${ }^{68}$ It then considered evidence of intent or "commercial exploitation," including. defendant's instructions to authors and artists preparing material for his books ${ }^{67}$ and the fictitious names printed in place of his own as publisher. The Court considered this evidence for two reasons: to establish scienter within the Smith holding, and to add further evidence of the prurient appeal of the materials. With respect to the latter, the Court inferred from the evidence of defendant's instructions to his authors and artists that he intended his materials to be sold to sexual deviates. This inference was based on the premise that no one else would buy this sort of material. At the same time, the Court referred to the Memoirs dictum in deciding that the defendant's evaluation of the material helped to determine whether the material in fact appealed to the prurient interests of its recipients.

In Ginzburg, the Court's entire attention was on the element of intent or "commercial exploitation." The Court assumed without deciding that Ginzburg's three publications ${ }^{68}$ could not be proved obscene standing apart from the context in which they had been sold. In fact, in the case of one publication, the Handbook, the Court admitted that an earlier distribution to a list of physicians and psychiatrists had been of some social value. ${ }^{69}$ However, the Court found that Ginzburg had played up the "sexually provocative" aspects of the publications in his advertising circulars. ${ }^{70}$ Small portions of the advertising had noted the social value of the publications, but the Court rejected this as mere

66 The Court made no mention of the patent offensiveness threshold or of the social value element, perhaps because petitioner argued in his defense to the allegation of prurient appeal that his publications "instead of stimulating the erotic, ... disgust and sicken." Mishkin v. New York, 383 U.S. 502, 508 (1966).

67 Defendant instructed his authors to write about "unusual sex ... very strong . . . clearly spelled out." $I d$. at 505 .

68 The publications were: EROS, a hardcover magazine; Liaison, a bi-weekly newsletter; and The Housewife's Handbook to Selective Promiscuity. See Ginzburg v. United States, 383 U.S. 463 (1966).

69 "The Government does not seriously contest the claim that the book has worth in such a controlled, or even neutral, environment." Id. at 472.

70 Ginzburg had mailed them through the post office in Middlesex, N.J., having failed to get mailing privileges at Intercourse and Blue Ball, $\mathrm{Pa}$. He had made reference to recent liberalization of the law of obscenity which allegedly made distribution of the publications possible and had promised a refund should the Post Office hold them up. Id. at $467-70$. 
"pretense."71 It inferred that Ginzburg had intended the publications to be bought solely for their prurient appeal. The Court concluded:

We perceive no threat to First Amendment guarantees in thus holding that in close cases evidence of pandering may be probative with respect to the nature of the material in question and thus satisfy the Roth test. $^{72}$

The Court added that it was not banning the publications per se: "All that will have been determined is that questionable publications are obscene in a context which brands them as obscene . ..."73

The hint in Ginzburg, as well as in Memoirs, is that pandering enters the equation when the social importance of the materials is at a minimum, a fact which presumably indicates a "close case."74 Mishkin suggests that it should lend weight to evidence of prurient appeal. This would tend to narrow the problem, although from all the Court tells us in Ginzburg, evidence of pandering may relate to the determination of the patent offensiveness threshold as well.

\section{The Intent Threshold Re-examined}

While evidence of intent in the 1966 cases was employed in several ways that are not clearly distinguished by the Court, three principal uses may be distilled from the opinions: (1) to shift the burden of proof with regard to determination of the audience; (2) to shift the burden of proof with regard to one or all of the three elements relating to the intrinsic nature of the materials in question-patent offensiveness, prurient appeal, and social value; (3) to determine scienter and establish intent as a third threshold in the obscenity test.

The first application of evidence of intent finds support from Professors Lockhart and McClure, who argue that the burden of proof should turn on the intrinsic nature of the materials. ${ }^{75}$ The more intrinsically pornographic the materials, the more important are the circumstances in which they are sold. A book of established literary merit will

71 Id. at 470 .

72 Id. at 474 .

73 Id. at 475 . The likelihood remains that the conviction of pandering publishers will effectively deter reputable publishers and sellers from marketing the publications involved, absent an express declaration by the court of their inherent non-obscenity. See The Supreme Court, 1965 Term, 80 HaRv. L. Rev. 91, 191 (1966).

74 The "close case" requirement for consideration of evidence of pandering is also criticized: "As a practical matter, this is a limitation that does not limit. When the standards themselves are as many and as vague as those now constituting obscenity law, a close case can only be what a court says it is." Note, More Ado About Dirty Books, 75 YALE L.J. 1364, 1388 (1966).

75 Lockhart \& McClure, supra note 47 , at 81-83. 
cast the burden of proving a susceptible primary audience heavily on the prosecution, regardless of the circumstances of distribution. ${ }^{76} \mathrm{But}$ for books on the borderline, evidence concerning the means of distribution will alter the burden of proof. Thus, while a seller of good repute will be presumed to be selling to mature audiences:

[I]f the dealer is one of little or no repute, who handles along with the Miller novels only girlie and nudist magazines and other books predominantly sexual in nature, law enforcement officials will certainly make use of this evidence and the dealer will then have difficulty proving that his audience for the Miller book is not a sexually immature one. ${ }^{77}$

In Ginzburg and Mishkin, the Court pounced upon this suggestion with enthusiasm. In both cases, upon circumstantial evidence of varying persuasiveness, the Court appears to have determined the nature of the audience solely on the basis of evidence of the publisher's intent. No effort was made in Ginzburg, for example, to ascertain whether or not the recipients of the advertising might take the publisher's claims to social importance seriously and buy the Handbook in a sincere effort to improve sexual relations with their spouses. In addition, it is unclear whether the burden of proof there was shifted as a result of the intrinsic pornographic nature of the literature or because the Court had found evidence of pandering. Because no determination was ever made as to the patent offensiveness of the materials, it would appear that the Gourt may have relied solely on Ginzburg's advertisements to establish the nature of the primary audience to which the materials would ultimately be sold. Under the implications of this rule, the publishers of advertisements for any number of films and books could conceivably find themselves in serious trouble. ${ }^{78}$

Far more troublesome was the Court's second use of evidence of intent. As first introduced in the Memoirs dictum, the new intent element went directly to the social value test. Essentially, the Court said that any slight literary value a given writing of minimal social value may have is negatived when that writing is exploited in a way that appeals solely to prurient interest and ignores the literary value. Similarly, in Mishkin, the Court said that evidence that the publisher thought of his books as appealing to the prurient interest of their intended recipients may help determine the fact of their prurient

76 Id. at 83. The authors refer to Lady Chatterley's Lover as an example of such a book. 77 Ibid.

78 Consider, for example, the standard newspaper advertisement used for Federico Fellini's film $8 \mathbb{z}$, which portrayed a man with a long whip surrounded by curvaceous Italian starlets. 
appeal. ${ }^{79}$ In both instances, the intent of the publisher helped to estabblish the ill effect threshold and may have been determinitive of the appeal of the materials to their audiences. ${ }^{80}$

In all three cases, the intent element functioned to shift the burden of proof with respect to the ill effect threshold. ${ }^{81}$ Introduction of evidence of pandering created an inference of the ill effect of the publications on their audience, shifting the burden to the defendant to prove his materials did not appeal solely to prurient interest and did in fact have social value for their primary recipient group. ${ }^{82}$ This application of intent fully contradicts the first purpose of such evidence, to determine what the primary audience will be so that the questions of prurient appeal and social value may be measured in terms of that audience. The Court has indicated, however, that the prurient appeal and social value of the materials as understood and intended by the publisherseller will be identical to the effect the materials have on their primary audience. Such an inference should have no more foundation in obscenity than it does in libel, where the plaintiff is required to prove that the third party understood the statements in question to be defamatory. ${ }^{83}$ The harm guarded against in obscenity law is the effect on sexually immature audiences of materials appealing solely to prurient interest. ${ }^{84}$ If such ill effect cannot be proved, then it would appear that Ginzburg and Mishkin are in jail merely for harboring bad intentions. ${ }^{85}$

70 "[A]ppellant's own evaluation of his material confirms such a finding (prurient appeal)." 383 U.S. at 510.

80 One comment seems to find relevant to the question of prurient appeal proofs based on the proposition "that a book is more likely to arouse a reader erotically if it is presented as a book that ought to arouse him erotically." The Supreme Court, 1965 Term, 80 HARv. L. REv. 91, 189-91 (1966). While the probative value of such evidence is somewhat doubtful, see text accompanying notes 83-84 infra, even should it be admissible, there is the danger arising from the 1966 decisions that it will be relied on exclusively in the determination of troublesome cases.

81 In one, Ginzburg, intent may also have shifted the burden of proof for the patent offensiveness threshold. As with prurient appeal, there may be some probative value in such evidence, but the danger that it may weigh too heavily in the determination of this threshold militates for its exclusion.

82 Again, the burden appears to shift not on the basis of the intrinsic indecency of the materials, but on the evidence of pandering alone.

83 In defamation cases, this determination is often made with the aid of testimony of selected recipients of the communication as to what effect the communication had on their regard for the plaintiff.

84 The necessity that the ill effect be a direct result of the words written is emphasized by Emerson in his words-actions distinction. Emerson, Toward a General Theory of the First Amendment, 72 YALE L.J. 877, 922 (1968).

85 Note, More Ado About Nothing, 75 Yale L.J. 1364, 1379 (1966). It has been suggested that such actions could be prosecuted as a criminal attempt. See Friedman, Mr. Justice Brennan: The First Decade, 80 HARv. L. REv. 7, 13 (1966). 
In a sense, the Court has treated the social value test as a defeasible privilege, ignoring its previous role as an independent element of the ill effect threshold. Hence, a finding of wrong intent should not have negatived this element in the same way that it negatived fair comment in libel where the privilege operated as a further defense in addition to the thresholds of the standard test. In defamation, even before Times, the courts had to find that the communication was false and defamatory before they could find for the plaintiff. The defendant's intent was irrelevant. When intent was introduced in Times, the Court was careful to preserve the independence of the three thresholds, requiring that each be separately proved before permitting recovery. ${ }^{86}$

The third application of evidence of intent, as a proof of scienter, is the only one functioning as an independent threshold like the intent element in Times. As used in Mishkin, evidence that the publisher knew he was appealing solely to the prurient interest of an immature audience is sufficient to determine the constitutional requirement of scienter set out in Smith. ${ }^{87}$ Unlike the other two applications of evidence of intent in these cases, this has no effect in determining the first two thresholds of the obscenity test. Were this to be the sole use of evidence of intent, the test for obscenity would be a truly multithreshold test.

What the history of libel law and the pre-1966 obscenity cases have illustrated is that where the legislature and the courts seek to regulate forms of speech, there is no single test that can accurately define that which is to be excluded and at the same time grant adequate protection to that which is socially useful and desirable. In Smith it was found that a standard of absolute liability unduly restricted freedom of the press. In Manual, the Court argued that proof of appeal to prurient interest was too broad; that materials had to be shown patently offensive as well. In Jacobellis and in Memoirs, the Court required that materials be utterly lacking in social value and hence appealing solely to prurient interest. The 1966 decisions represent a rather startling reversal of the pattern by allowing a single element, "commercial exploitation," to permeate and possibly dominate the entire test. The use of a singlethreshold test, one that depends entirely on the intent of the defendant, endangers the constitutional right of free speech by broadening the range of prosecutions permitted ${ }^{88}$ and thus drastically altering the course set by the Court over the past decade.

86 For support of the principle of independent proofs of the elements of obscenity, see 19 STAN. L. Rev. 167, 181 (1966).

87 The Court quotes the interpretation of the scienter element by the New York court as the "calculated purveyance of filth." 383 U.S. at 510.

88 "It is of course true that in some circumstances variable obscenity may effectively 


\section{Times v. Ginzburg: Some Distinctions}

Having applied the threshold approach of libel to obscenity, it is necessary to point out some significant differences between the two areas of law and the way in which the multi-threshold test affects them. While the similarities between the two based on their common foundation in the first amendment are striking, their individual peculiarities lend force to the conclusion that obscenity defendants should, at the very least, be given the same protection that is now given in libel law.

It is significant initially to note that the defendant won in Times, while in two of the three obscenity cases the publishers were convicted. In instituting the "variable obscenity" theory in Ginzburg and its two companion cases, it is strikingly apparent that the Court considered the cases against a background markedly different from that in Times, where the overriding emphasis was on further protection of speech. Perhaps this attitude of restraint reflected in the new decisions was caused by an unarticulated desire on the part of the Court to redraw the boundaries of obscenity law in order to obtain more convictions. ${ }^{89}$

However, a more persuasive reason for this different perspective may be that the Court takes a more protective attitude toward communications involving politics than toward communications dealing with sex. With the issues of seditious libel and censorship by the government of its critics lurking in the background, the Court had little difficulty in coming to the defense of an institution such as the New York Times in a somewhat spurious libel suit. The defense of a New York smut salesman has less appeal to judicial sensibilities. Whereas free and open political debate is an absolute essential of the democratic system, it is more difficult to find a comparable compulsion for wide-open discussion of sex. Yet in Burstyn the Court conceded no constitutional difference between entertainment and the reporting of politics, ${ }^{90}$ and it would therefore appear that the law calls for equal treatment of these two areas of speech.

A significant difference between libel and obscenity is that in libel one is generally dealing with ideas and the reporting of facts, while in obscenity litigation the materials are questioned for the form in which they present themes or images; the courts are dealing with questions of tastes and esthetics in obscenity, not with accuracy as to facts and

deprive the sexually immature, including some harmless old men, of material that in other circumstances would not be obscene and might even have great social importance." Lockhart \& McClure, supra note 47 , at 84 .

89 See 45 TEXas L. REv. 1382, 1389 (1966).

90 Joseph Burstyn, Inc. v. Wilson, 343 U.S. 495 (1952); see note 60 supra. 
opinions. Many writers and artists are attempting to convey images through their work, the final impression of the work being created in the mind of the individual recipient. ${ }^{91}$ In this context, the notion of "social value" is somewhat inimical to the issues at hand. Despite the Court's effort to make social value interchangeable with "literary or scientific or artistic value,"92 it is obviously extremely difficult to determine whether a given primary audience finds a magazine utterly without social (literary) value; 93 what may be of literary value to the uneducated man may be utterly worthless to the Ph.D. ${ }^{94}$ Where the critical questions turn on the means and form of expression rather than its content, there is a clear danger of turning the rule into a "gentlemen's privilege," where an educated court and expert witnesses may be unable to see what some may regard as literary merit. Certainly under the rules of Ginzburg and Mishkin, where social value was determined by the circumstances of distribution, such discrimination against those with less sophisticated literary tastes is inevitable. The conclusion to be drawn from these considerations involving the inherent difficulty of determining what is obscene is that the test for such a determination should be overbroad in order sufficiently to protect marginal materials. In fact, there would appear to be more compelling reason for building this prophylactic protection into an obscenity test than there is for its existence in a libel formula since the more objective nature of libel determinations make them less prone to error.

The last point that sets obscenity apart from libel is that in Ginzburg

91 Defining "work of art" as a viewer's perception of and response to an art object, Professor Kaplan says "obscenity is a property of the resultant work and not of the object out of context." Kaplan, Obscenity as an Esthetic Category, 20 LAw \& CoNTEMP. ProB. 544,545 (1955).

92 Jacobellis v. Ohio, 378 U.S. 184, 191 (1964).

93 Indeed, how does one go about defining "appeal to prurient interest" when dealing with a group of sexual deviates? See the dissenting opinion of Mr. Justice Douglas in Ginzburg v. United States, 383 U.S. 463, 491 (1966).

94 Concomitantly, Shakespeare must be deemed to be totally lacking in social or literary importance to those unable to comprehend his works.

Also worth noting here is the data developed by the (Kinsey) Institute for Sex Research "showing that, generally, better educated persons are more responsive to pornography because they are more imaginative and better able to conceptualize than persons of low social and educational status; the latter are less likely to get excited about a picture with which they can 'do nothing." "Magrath, The Obscenity Cases: Grapes of Roth, 1966 Sup. Cr. Rev. 7, 65-66.

For the argument that pornography may be a useful medium for modern writing see Michelson, Apology for Pornography, The New Republic, Dec. 10, 1966, p. 21.

It is interesting to note that the social value test is implicit in Times whereas it is explicit in obscenity law. The relatively objective Times rule tends to exclude materials of no social value but does not use that rather vague term as a criterion of the test. See note 38 supra and accompanying text. 
a man was sent to prison for five years; in Times, a newspaper was threatened with a money judgment. The fact that much of obscenity law involves criminal prosecution and the possibility of a prison sentence would seem to demand that the defendant's right to free expression be as fully protected as possible, for not only is a source of expression being restricted, but its publisher is being imprisoned. Thus it is probable that pressure on publishers to observe a safer margin will result in the operational illegality of legitimate materials dealing with sex because of the threat of greater sanctions. ${ }^{95}$

\section{Some Concluding Observations}

Any constitutional test for obscenity must focus on the protection of expression concerning sex that is of only marginal value in order to protect that of real importance. It is always easy to find zealous censors, less easy to find those who will support speech unpopular with the majority. ${ }^{96}$ To counteract this tendency, the Times opinion offers an admirable model.

The difficulties with defining a clearcut rule for obscenity are manifold. The standards of the community toward discussion of sexual matters change so rapidly that any rule must be subject to almost continuous re-evaluation. Standards vary so widely among groups in society that what shocks one person bores the next and is a source of "psychic autoeroticism" to yet another. Moreover, any judgment as to the obscenity of a work necessarily involves subjective determination of the taste with which it was written. The danger here, of course, is that the tastes of one group will be imposed on others. Finally, it is difficult to identify and to measure the social and individual harm the law wishes to punish. ${ }^{97}$ It is perhaps for some of these reasons that Justices Black and Douglas have been moved to vote for the unconstitutionality of all obscenity regulation.

But a persistent majority of the Court has insisted on the constitu-

95 One comment refers to this as the "chilling effect." The Supreme Court, 1965 Term, 80 HaRv. L. Rev. 91, 193 (1966).

98 See Emerson, supra note 84, at 887-93. "A system of free expression can be successful only when it rests upon the strongest possible commitment to the positive right and the narrowest possible basis for exceptions. And any such exceptions must be clear-cut, precise and readily controlled. Otherwise the forces that press toward restriction will break through the openings, and freedom of expression will become the exception and suppression the rule." Id. at 889.

97 See generally United States v. Roth, 237 F.2d 796, 812-17 (2d Cir. 1956) (appendix to concurring opinion of Frank, J.); Cairns, Paul \& Wishner, Sex Censorship: The Assumptions of Anti-Obscenity Laws and the Empirical Evidence, 46 MiNN. L. REv. 1009 (1962); Lockhart \& McClure, supra note 47; ST. John-STEVAS, OBSCENITY AND THE LAW (1956). See also note 47 supra. 
tionality of some regulation of pornographic materials. Again, Times offers an admirable model for the construction of a rule. The rule must overprotect all speech to protect that which is valuable. The test must rely on the most objective elements possible. It must be as precise as possible, both to serve notice on those who may be criminally prosecuted and to guarantee consistency in the courts. For these purposes, the multi-threshold test in Times seems most suitable. The Court should first require determination of whether the material is inherently indecent. Here, it would be better not to apply the variable obscenity theory, ${ }^{98}$ but rather to judge the offensiveness of the material by contemporary national standards as in Roth and Manual. Second, the test should include an ill effect or harm threshold, which will define what about the material is harmful enough to put it beyond first amendment protection. If this harm is the titillation of sexually immature minds, it should be so stated. In this instance, it is sensible to again borrow from libel law in judging the effect by determining its impact on the actual primary audience. Evidence of the intended audience may be helpful here, but surely not conclusive. A counterbalance to the ill effect element should be required proof that the material has no value to the primary audience other than its capacity to bring about ${ }^{\circ}$ the harm or ill effect proscribed. The third independent threshold should be the intent of the publisher or distributor of the materials to exploit the weakness of the primary recipient group for the particular ill effect defined. ${ }^{99}$ This element should be independent and should not be a tool for determining or redirecting the burden of proof for either of the other two thresholds. The defendant must have known that the primary recipient group was susceptible, that the material would have the ill effect defined upon the group, and that members of the group would buy the material primarily to receive the defined ill effect.

Such a test is not altogether inconsistent with Ginzburg and its companion cases. Virtually every portion of this test is suggested by one or more of the Justices. What is basically different, and what is crucial to the success of the test, is that each threshold be independent of the other two.

98 See nòte 52 supra.

99 An alternative might be a showing that the defendant was utterly without "esthetic intent." Cf. Kaplan, supra note 92 , at 548. 